\title{
ASSOCIATION BETWEEN CIGARETTE ADVERTISEMENT, PEER GROUP, PARENTAL EDUCATION, FAMILY INCOME, AND POCKET MONEY WITH SMOKING BEHAVIOR AMONG ADOLESCENTS IN KARANGANYAR DISTRICT, CENTRAL JAVA
}

\author{
Windiarti Dwi Purnaningrum¹,2), Hermanu Joebagio3), Bhisma Murti2) \\ 1)Health Polytechnics, Ministry of Health, Surakarta \\ 2)Masters Program in Public Health, Sebelas Maret University \\ 3)Masters Program in Historical Education, Sebelas Maret University
}

\begin{abstract}
Background: Adolescents are susceptible to positive and negative influences from the social environment. One of the negative influences is smoking behavior. Smoking in adolescents can have deleterous effect on health and academic achievement. This study aimed to determine the association between cigarette advertisement, peer group, parental education, family income, and pocket money on smoking behavior among adolescents.

Subjects and Method: This was an analytic observational study using cross-sectional design. This study was carried out in Colomadu Sub district, Karanganyar District, Central Java. A sample of 100 teenagers was selected for this study. The dependent variable was smoking behavior. The independent variables were exposure to cigarette advertisement, peer group, parental education, family income, and pocket money. The data were collected by a set of questionnaire. The data were analyzed by logistic regression.

Results: Smoking behavior in adolescents was associated with exposure to cigarette advertisement $(\mathrm{OR}=22.58 ; 95 \% \mathrm{CI}=2.42$ to $210.69 ; \mathrm{p}=0.006)$, peer group $(\mathrm{OR}=44.00 ; 95 \% \mathrm{CI}=3.99$ to $485.33 ; \mathrm{p}=0.002)$, parental education $(\mathrm{OR}=36.92 ; 95 \% \mathrm{CI}=3.12$ to $427.81 ; \mathrm{p}=0.004)$, family income $(\mathrm{OR}=0.09$; $95 \% \mathrm{CI}=0.01$ to $0.97 ; \mathrm{p}=0.047)$, and pocket money $(\mathrm{OR}=10.56$; $95 \% \mathrm{CI}=$ 1.22 to $91.56 ; \mathrm{p}=0.032)$.

Conclusion: Smoking behavior in adolescents was associated with exposure to cigerrete advertisement, peer group, parental education, family income, and pocket money.
\end{abstract}

Keywords: cigarette advertisement, peer group, parental education, family income, pocket money

Correspondence: Windiarti Dwi Purnaningrum. Health Polytechnics, Ministry of Health, Surakarta. Email: windiartidwi@gmail.com.

Mobile: +628562995373 . 